\title{
Koncept incumbency advantage v českých senátních volbách ${ }^{1}$
}

\author{
The Incumbency Advantage Concept In Czech Senate Elections
}

\author{
MARCELA VoŽENÍLKOVÁ, JAN HEJTMÁNEK²
}

\begin{abstract}
The concept of incumbency advantage has, for more than 40 years, been a frequently discussed topic in American political science. The fact that incumbents, for various reasons, have a noticeable advantage over their challengers also brings new questions, notably what the sources of this advantage are and how exactly this advantage is reflected in the elections. Our aim was to apply the concept of incumbency advantage to the Caech political environment, specifically the Senate elections. Our research faced several challenges stemming mainly from fundamental differences between the political systems of the United States and the Czech Republic. We had to adjust the existing theoretical knowledge and measuring instruments in order to perform an analysis of the Czech Senate elections from 1998 to 2012 and answer the main research question of whether there is or not an advantage for incumbent senators in the Czech Republic. On the basis of the analysis of data from the election results, this could not be confirmed. To the contrary, in many cases, the very fact that a particular politician defends a mandate may in fact be a disadvantage. Such a claim is also in line with several other studies with a similar theme and we hope our paper will be an impulse for further research on the topic of incumbency advantage in the Caech Republic.
\end{abstract}

Keywords: Elections, Incumbency Advantage, Czech Senate

\section{1. Úvodem}

Individuální charakteristiky kandidátů mohou sloužit voličům jako zkratky a jako volební zdroje. To jinými slovy znamená, že méně informovaní voliči používají např̀. věk, vzdělání či bydliště kandidáta jako informační vodítko při rozhodování, komu odevzdají svůj hlas. Jednou z těchto individuálních charakteristik je

\footnotetext{
1 Text byl zpracován v rámci projektu specifického výzkumu Katedry politologie FSS MU „Aktuální problémy politologického výzkumu" (kód MUNI/A/1342/2014).

2 Oba autoři jsou interními doktorandy na Katedře politologie Fakulty sociálních studií Masarykovy univerzity, Joštova 10, 60200 Brno, Česká republika / Czech Republic. Kontakty na autory:marcelavozenilkova@mail.muni.cz, hejtmanek.j@seznam.cz.
} 
i obhajoba mandátu. Pokud politik obhajuje svůj post, disponuje výhodou oproti ostatním kandidátům, jelikož voliči mohou daný fakt vyhodnotit jako plusový bod pro tohoto politika (znají ho, osvědčil se $\mathrm{v}$ úradu atp.). Výhody, které daný politik může využívat, však tímto nekončí.

Koncept incumbency advantage (IA), neboli koncept výhody obhájce, ${ }^{3}$ se objevil v americké literatuře na přelomu 60. a 70. let 20. století, aby vysvětlil úspěšnost držitelů úřadů při pokusech své posty obhájit. Až $90 \%$ takových kandidátů bylo znovuzvoleno, a proto odborníci, kteří nejdřive upozornili na posun v růstu výhod obhájců, jej označili jako úpadek volební soutěže ${ }^{4}$ Jacobson 1987: 127; King a Gelman 1991: 111). Snaha vysvětlit tuto výhodu se stala jedním dz určujících zájmů americké odborné literatury druhé poloviny 20. století. Pokusů přenést koncept výhody obhájce a jeho operacionalizaci na další země, které se více či méně prúbližují fungování amerického stranicko-politického systému, však není mnoho.

Ačkoliv v české politické vědě patř́ témata související s volbami ke stále častějšímu předmětu výzkumu tuzemských politologů (Holzer et al. 2009: 109), stále ještě existují témata, která nejsou dostatečně prozkoumána i přesto, že se jim zahraniční autoři věnují poměrně často a že by tato témata mohla být v př́padě České republiky zajímavá. Výjimkou není ani koncept výhody obhájce. V českém politologickém prostředí se setkáváme jen s nemnoha zmínkami o výhodě držitelů úřadu. Např. Josef Bernard (2012) hovoří o „,inkumbenčním efektu“ (incumbency effect) a hodnotí jej jako významný parametr rozhodování voličů v komunálních volbách. Tomáš Lebeda (2011) v př́padě senátních voleb hovoří v tomto kontextu spíše o nevýhodě.

Tento text jako jeden z prvních seznamuje čtenáře s konceptualizací a operacionalizací pojmu výhody obhájce. Jelikož bude, jak popíšeme dále, koncept výhody obhájce spojen v naší práci spíše s osobnostmi (Fowler a Hall 2012), a tím pádem zejména většinovými volebními systémy, připadá v úvahu pro ČR pouze aplikace na volby senátní z důvodu pojetí konceptu jako výhody pro konkrétního kandidáta, který obhajuje mandát (ne stranické výhody, viz níže). To můžeme hodnotit jako výzvu, jelikož prozatím žádná ze studií nevěnovala

\footnotetext{
3 Jelikož, jak je uvedeno i dále, není téma našeho výzkumu v české politologii dosud př́liš zpracováno, není prozatím jednotná ani terminologie. $\mathrm{V}$ textu dále pracujeme s pojmy výhoda obhájce (ekvivalent anglického incumbency advantage) a obhájce mandátu (ekvivalent pojmu incumbent). Josef Bernard (2012) ale pro stejný jev používá termín inkumbenční efekt, resp. inkumbent. Podle našeho názoru je ale bez problémů možné využít českého překladu, kterého se dále v textu držíme.

${ }^{4}$ Např. Albert Cover (1977: 531-536) ve svém výzkumu zmiňuje mj. jako základní příčinu rostoucí výhody obhájce změny ve volebním chování, zejména pokles stranické identifikace amerických voličů, která již v některých prrípadech hrála jen minimální roli. Cover ukazuje, že voliči, kteří se identifikují se stranou vyzyvatele ve volebním klání, v polovině př́ípadů hlasují pro kandidáta protistrany, pokud je tento kandidát obhájcem mandátu.
} 
pozornost vícestranické soutěži za užití dvoukolového většinového volebního systému. V zásadě půjde zejména o to navrhnout konkrétní postup, jak v podmínkách České republiky měrit výhodu obhájce. Je proto nutné upozornit, že tento text představuje první z návrhů $\mathrm{k}$ diskuzi o operacionalizaci IA pro specifika českých senátních voleb s užitím zavedených měření i s návrhem nového hodnocení postavení držitelů úřadu, přičemž se ptáme na otázku, zda v českých senátních volbách existuje výhoda obhájce mandátu a jaká je príŕčina této (ne)existence?

\section{Koncept incumbency advantage}

Koncept výhody obhájce (IA) se v americké literatuře objevuje již minimálně od 60. let minulého století. Různí autoři (Stokes a Miller 1962, Cummings 1966: 6875, Erikson 1971) si začali všímat toho, že ve volbách do obou komor amerického parlamentu existuje určitá výhoda, kterou mají stávající poslanci či senátoři oproti kandidátům, kteři se o mandát ucházejí jako jejich vyzyvatelé. ${ }^{5}$ Tato problematika se poté stala jedním z vůbec nejčastějších témat výzkumů amerických politologů a sociologů zabývajících se volebním chováním, nicméně kromě čistě empirických studií se autoři zaměřili zejména na dvě subtémata. A to zaprvé, co je příčinou výhody obhájce, a za druhé, jak tuto výhodu měrit. Zejména druhá z těchto otázek není uspokojivě zodpovězena dodnes.

Jak a proč vzniká výhoda obhájců mandátu? Odborníci identifikovali různé faktory, které mohou být zodpovědné za volební výhodu obhájce (viz např. Levitt a Wolfram 1997). Nejčastěji se však v literatuře setkáváme s pěti vysvětlujícími charakteristikami $\mathrm{IA}^{6}$ :

1) Vyšší kvalita obhájců než vyzyvatelů

\footnotetext{
${ }^{5} \mathrm{~V}$ literatuře je koncept IA nejčastěji popisován jako volební výhoda kandidáta, který je v daných volbách držitelem úrudu (incumbent), o který se bojuje, a který kandiduje na znovuzvolení, oproti jeho protikandidátům, vyzyvatelům (challengers). Lze konstatovat, že držitelé úřadů jsou ve volbách procentuálně výrazně úspěšnější než kandidáti, kteří bojují o tzv. open-seat (tj. mandát, o který neusiluje obhájce mandátu). IA však může být konceptualizována i jako stranická výhoda. Osobní výhoda roste (nejvíce) mezi první kandidaturou politika a druhou kandidaturou se statutem úřadujícího politika. Z osobní výhody pro úřadujícího politika je odvozená výhoda pro jeho/její stranu. Pokud kvalita kandidáta nehraje roli, osobní a stranická volební výhoda budou totožné (viz Erikson a Titiunik 2013: 3).

6 Jessica Trounstine (2009) veškeré možné příčiny výhody obhájce shrnuje pouze do tř́ zastřešujících kategorií. Zaprvé se jedná o selekční efekt (selection), kdy samotný fakt, že byl kandidát již jednou zvolen, představuje pro voliče zkratku pro možný výběr tohoto kandidáta. Druhou kategorií je reakce (responsiveness), kdy voliči reagují na úspěšné působení kandidáta v předchozím volebním období a jeho získanou reputaci. Poslední kategorií jsou institucionální faktory (institutional insulation), které umožňují obhájcům př́stup ke zdrojům, a to nejen finančním, které jejich vyzyvatelé k dispozici nemají.
} 
Kvalita se vztahuje především k vnímání kandidáta jako schopného, jelikož už jednou byl zvolen pro daný úřad, ale také ke kvalitě jeho práce $\mathrm{v}$ uplynulém funkčním období. Jedná se i o nové zkušenosti, které v daném úřadu mohl politik nabýt. Pro voliče je podle Alana Abramowitze (1975: 683-684) důležité primárně to, že jsou spokojeni s dosavadním výkonem kandidáta ve funkci a nemají důvod hlasovat ve volbách pro jeho vyzyvatele. Vliv obhajování mandátu na zvolení může být chápán jako selekční efekt, kdy úradující politici jsou v průměru kvalitnějšími kandidáty než jejich vyzyvatelé (Trounstine 2009; Stone et al. 2010 citováno dle Bernard 2012).

2) Obhájci jsou pro stranu výhodnější volbou v obvodě

Dalšími výhodami obhajování mandátu, kterými může kandidát ovlivnit nominaci stranou i zisk hlasů $\mathrm{v}$ obvodě, jsou bezesporu prrístup $\mathrm{k}$ médiím (vystupování na veřejnosti spojené s povinnostmi $\mathrm{v}$ úřadu), širší možnosti financování kampaně, použití úřadu $\mathrm{k}$ výměně politických výhod za př́spěvek na kampaň a tzv. franking privileges (což jsou de facto opět služby, které z pozice úradu může politik poskytnout směrem ke svému volebnímu obvodu). Nominující subjekt díky těmto výhodám může např. ušetřit za kampaň v daném obvodě (Trounstine 2009).

3) Držitelé úřadů „vystraši““ potenciální vyzyvatele

4) Obhájci využívají svůj úřad k nepřímému nákupu hlasů v jejich obvodě (legislative spending)

V bodech 3 a 4 odkazujeme na nepřímý efekt IA. Přímý efekt vyplývá ze zdrojů a benefitů úřadu, které má úřadující politik $\mathrm{k}$ dispozici, plyne jednoduše ze statutu úřadujícího politika. Nepř́mý efekt vychází z prímého, odkazuje na schopnost úradujícího politika odstrašit vyzyvatele (hovoř́me o tzv. scare-off advantage) a plyne $\mathrm{z}$ vyšší kvality kandidáta - obhájce mandátu (porovnej Redmond a Regan 2013: 2; Cox a Katz 1996: 479), ale také ze samotného faktu výhod obhájců, kterými vyzyvatelé nedisponují. Bod 3 odkazuje na situaci, kdy již fakt, že v obvodě kandiduje obhájce mandátu, vede ke změně v okruhu jeho prŕpadných vyzyvatelů. Protikandidáti např. raději kandidují v jiném volebním obvodě, nebo se rozhodnou volební soutěže se vůbec neúčastnit. Kandidatura silného obhájce v určitém obvodě může mít vliv na nasazování kandidátů jednotlivých stran do konkrétních obvodů, nebo rozložení finančních prostředků na kampaň. V př́padě bodu 4 lze jako príklad uvést to, že držitelé legislativních úřadů mohou ovlivnit daně či monetární politiku, použít svưj úřad k výměně politických výhod za př́spěvek na kampaň, hlasovat za legislativu, která reflektuje ideologické nebo ekonomické zájmy jejich obvodu atp. 
5) Elektorát snáze rozpozná politika, který je v úřadě (name-recognition) ${ }^{7}$

Obhajování mandátu je individuální charakteristikou kandidátů (vedle např. pohlaví, etnické př́slušnosti, věku, zaměstnání atp.), kterou lze chápat jako „zkratku“ pro voliče ve volbách s nízkou informovaností (low information elections, viz např. Raymond 1992). Tyto charakteristiky mají roli pomocných kritérií, která voliči využívají v situaci, kdy nemají dostatek informaci, podle nichž by se mohli rozhodnout, který z kandidátů by nejlépe reprezentoval jejich zájmy. Obhajování mandátu má mezi individuálními charakteristikami kandidátů specifické postavení. Nejedná se o sociodemografickou, ale spíše politickou charakteristiku jednotlivých kandidátů, která má ovšem na volební úspěšnost zásadní vliv (Bernard 2012: 616). Pokud voliči vědí, kdo z kandidátů ve volbách je v současné době úřadujícím politikem, mohou tuto informaci využít jako „zkratku“, která jim pomáhá v rozhodování, a dané kandidáty upřednostnit před vyzyvateli, kteří jim př́padají př́liš neznámí (viz např. Krehbiel a Wright 1983). ${ }^{8}$

$\mathrm{Na}$ druhou stranu je nutné si uvědomit, že IA není pravidlem - napřr. v obvodech s tradičně silnou podporou konkrétní politické strany je IA kandidáta jiného subjektu nižší, nebo naopak, IA je obecně vyšší, pokud hovoříme o viditelnějších úradech (nap̌r. při srovnání voleb prvního a druhého řádu; viz Ashworth a de Mesquita 2008: 1006-1007).

\section{Operacionalizace konceptu}

Měření volební výhody úřadujících politiků je vystaveno několika výzvám. Zaprvé, kandidáti, kteří zvítězili ve volbách, mají tendenci být systematicky odlišní od těch, kterým se to nepodařilo (viz výše) - zkušený politik pravděpodobněji obdrží větší podíl hlasů. Zadruhé, úřadující politici mohou získat nebo ztratit hlasy na základě kvality svých oponentů. Zatřetí, úřadující politici uvažují strategicky o tom, kdy odejít z politiky, a mají tendenci svou kariéru ukončit tehdy, kdy se jejich vyhlídky na znovuzvolení zhoršsi (Erikson a Titiunik 2013: 2). Začtvrté, volební výhoda může vycházet rovněž ze skutečnosti, že mateřská strana je právě obhájcem mandátu (partisan incumbency). Tyto aspekty je nutné prri posuzování IA brát $\mathrm{v}$ potaz.

Hlavním problémem empirického zkoumání IA jsou multidimenzionální aspekty kandidátovy kvality, jako jsou charisma, šarm či inteligence. Nelze je totiž pozorovat a kvantifikovat (Redmond a Regan 2013: 3; Cox a Katz 1996: 482). Nelze opomíjet ani obtížné rozlišení osobní a stranické výhody. Problém operacionalizace konceptu se proto stal předmětem zájmu celé řady odborných

\footnotetext{
7 Porovnej Campbell 1983; Cox a Katz 1996; Ansolabehere, Snyder a Stewart 2000; Coop 2014, Carthy a Richie 2012; Lee 2001; Spahn 2011; Bernard 2012; Fowler a Hall 2012.

${ }^{8}$ Autoři se však nepř́liš často věnují úpadku politických stran a růstu personalizace politiky jako vysvětlující proměnné IA.
} 
studií. Ačkoli lze konstatovat, že drtivá většina textů se opírá o operacionalizaci dle Gelmana a Kinga (1990), dodnes nepanuje shoda ohledně toho, jak vlastně IA měřit, resp. na co konkrétně se zaměřit.'

Většina autorů se zaměřuje výhradně na posouzení IA zvýšením podílu hlasů. V tomto ohledu je nejcitovanějším text Gelmana a Kinga (1990), v němž autoři definují teoretickou výhodu obhájce pro jeden legislativní volební obvod jako

$$
\Psi=\mathrm{w}^{(1)}-\mathrm{w}^{(0)},
$$

kde $\mathrm{w}^{(l)}$ je podíl hlasů, které obdržel úřadující zákonodárce $\mathrm{v}$ jeho/jejím obvodu, pokud on/ona kandiduje proti hlavní opoziční straně, a $\mathrm{w}^{(0)}$ je podíl hlasů, které obdržela strana, jejíž politik právě zastává úřad v obvodě, pokud úřadující zákonodárce nekandiduje a všechny hlavní strany soutěží o tento volný mandát. Agregovaná výhoda obhájce je definována pro celý zákonodárný sbor jako průměr IA pro všechny obvody ve všeobecných volbách (Gelman a King 1990). Vzorec má ale jeden základní problém, a to ten, že logicky nikdy nezjistíme hodnotu obou využitých podílů. $V$ prípadě, že obhájce kandiduje, budeme mít $\mathrm{k}$ dispozici pouze hodnotu $\mathrm{w}^{(\mathrm{l})}$, $\mathrm{v}$ opačném př́padě pouze hodnotu $\mathrm{w}^{(\mathrm{o})}$. Proto různí autoři navrhují různé metody měrení výhody obhájce, které si s tímto faktem dokáží, byt' třeba jen částečně, poradit.

Dvě základní a nejčastěji užívané metody jsou v literatuře (Payne 1980, Gelman a King 1990: 1144-1149) označeny jako nárůst u obhájce (sophomore surge, SS) a propad u odstupujícího (retirement slump, RS). Nárůst u obhájce mưžeme definovat jako průměrný nárůst podílu hlasů pro kandidáty, kteří poprvé zvítězili v předchozích volbách a znovu se ucházeli o mandát ve volbách následujících (Gelman a King 1990: 1144-1145). Propad u odstupujícího můžeme definovat jako průměrnou ztrátu podílu hlasů pro strany, jejichž kandidáti zvítězili v předchozích volbách, ale nekandidovali ve volbách současných (Tamtéž). Gelman a King poté ukazují, že obě výše zmíněné metody výpočtu výhody obhájce jsou do značné míry nepřesné a navrhují svůj vlastní model založený na lineární regresi:

$$
\mathrm{E}\left(\mathrm{v}_{2}\right)=\beta_{0}+\beta_{1} \mathrm{v}_{1}+\beta_{2} \mathrm{P}_{2}+\Psi \mathrm{I}_{2},
$$

kde $I_{2}$ se rovná 1 , pokud demokratický úřadující politik kandiduje, 0 , pokud nekandiduje, -1 , pokud kandiduje republikánský úřadující politik. $\mathrm{P}_{2}$ se rovná 1 , pokud vyhraje ve sledovaných volbách demokrat, a -1, pokud vyhraje republikán. Parametr v značí proporci hlasů demokratů ve volbách 1, prípadně 2 (Gelman a King 1990: 1150-1151, King a Gelman 1991: 112). Samotnou výhodu obhájce poté určuje parametr $\psi$. Gelmanova a Kingova operacionalizace IA čelí statistickým problémům a byla dalšími autory mnohokrát kritizována ${ }^{10}$

\footnotetext{
${ }_{9}^{9}$ Porovnej např. Ashworth a de Mesquita 2008, Spahn 2011.

${ }^{10}$ Porovnej Alford a Brady 1988, Ansolabehere a Snyder 2004, Praino a Stockemer 2012.
} 
i modifikována. Nejčastěji modifikovaným prvkem Gelmanovy a Kingovy operacionalizace IA je „term limits“ - vztahuje se ke konceptu SS a nezohlednění času (volebního obdobî) jednotlivých kandidátů. ${ }^{11}$ Katz a King (1999: 17) poté upozorňují, že daný model je obvykle aplikován bez kontroly a bez jakéhokoli znaku statistického modelu, který by naznačoval, že $\mathrm{v}$ systému, který je analyzován, působí více než dvě strany. Právě z tohoto důvodu nelze tento model aplikovat $\mathrm{v}$ prostředí českých senátních voleb, čemuž se podrobně věnujeme v kapitole 4.

Velmi důležité je rozlišení mezi stranickou a individuální výhodou obhájce. Stranická IA vyplývá z toho, že nominující strana zastává úřad (at’ již na dané úrovni voleb, nebo, jako v našem prrípadě, má zastoupení na půdě Poslanecké sněmovny). $V$ tomto př́padě již nezáleží takovou měrou na tom, zda kandidát dřive úřad zastával, či ne. Rozlišení mezi personální a stranickou IA se stalo ožehavým tématem celého konceptu a jeho operacionalizace (vedle již nastíněných modifikací Gelmanova a Kingova způsobu operacionalizace IA), jelikož řada autorů je toho názoru, že nelze relevantně hovořit o IA pro jednotlivce, pokud neuvážíme i IA pro nominující subjekt. Mezi tyto autory se raadí např̀. Fowler a Hall (2012), kteři ve svém textu zjišt’ují (ovšem měřeno opět pro americké legislativní volby), že výhoda pro jednotlivce je nepoměrně vyšší, než je tomu v prŕípadě stranické výhody, která je dle nich zanedbatelná. K měření osobní výhody používají již zmíněné koncepty SS a RS, které však dle nich měří pouze tzv. personal vote, nedokáží tedy odlišit stranickou IA. Osobní výhoda je dle nich definovatelná jako

$$
\mathrm{V}_{\mathrm{i}}(1)-\mathrm{V}_{\mathrm{i}}(0)
$$

kde $\mathrm{V}_{\mathrm{i}}(0)$ je dvoustranický podíl hlasů, které obdržel kandidát ve volném obvodě, ve kterém byl předchozí obhájce mandátu ze stejné strany, a kde $V_{i}(1)$ je dvoustranický podíl hlasů kandidáta ve stejném čase ve stejném obvodě, prričemž se předpokládá, že daný kandidát byl v předchozím období držitelem úradu a využil proto ve volbách všechny výhody, které obhajování mandátu přináší. Stranickou výhodu definují jako

$$
\mathrm{W}_{\mathrm{i}}(1)-\mathrm{W}_{\mathrm{i}}(2) / 2 \text {, }
$$

kde $\mathrm{W}_{\mathrm{i}}(1)$ je dvoustranický podíl hlasů obdržených demokratickým kandidátem ve volném obvodě j v čase t, kde předchozí obhájce mandátu byl

11 Gelman a King používají SS pouze pro hodnocení IA mezi prvním zvolením a prvním znovuzvolením. Ačkoli je dle Praino a Stockemera (2012) nutné zohlednit i další období, připouštějí, že nárůst je nejvyšší v období prvního až čtvrtého pokusu o znovuzvolení (zásadně se nelišî). Proto je nutné připomenout, že koncept je navržen pro americké kongresové volby, kde volební cyklus trvá pouhé dva roky (Dvořáková 2002: 98), a je pravděpodobnější, že politik bude usilovat o znovuzvolení vícekrát, než tomu bude v případě českých senátních voleb, které stanovují šestileté funkční období. 
demokrat, a kde $\mathrm{W}_{\mathrm{i}}(2)$ je dvoustranický podíl hlasů obdržených demokratickým kandidátem ve stejném obvodu j v čase $t$, ale s předchozím republikánským obhájcem mandátu. Problémem tohoto modelu nicméně je, že nelze pozorovat obě hodnoty současně (stejně jako v definici Gelmana a Kinga) a že jakmile je držitelem úřadu jednotlivec, je obhájcem mandátu také nominující strana. Tento problém lze opomenout, hovoříme-li o přenesení modelu na podmínky českých senátních voleb. V tomto prípadě lze definovat jako obhajující stranu tu, která právě zasedá $v$ Poslanecké sněmovně (vzešla z voleb prvního řádu). Druhý problém však již není řešitelný, a to je opět požadavek two-party vote při výpočtu.

Ačkoli se i voperacionalizaci dá zachytit rozdíl mezi tím, zda mandát obhajuje kandidát, či strana, dosavadní výzkum se zaměřuje na volby, ve kterých proti sobě stojí individuální kandidáti - tj. volby za podmínek takového volebního systému, kde volič volí jednotlivé kandidáty, nikoliv politické strany. Ve smyslu výhody konkrétního kandidáta, který obhajuje mandát, je vnímán koncept incumbency advantage i v tomto textu. Proto jej lze aplikovat pouze na české senátní volby. Kritériu většinového volebního systému by odpovídal i charakter prezidentských voleb, nicméně přímá volba prezidenta se dosud konala pouze jednou, a tudíž zkoumání prezidentských voleb z hlediska výhody obhájce mandátu ztrácí veškerý smysl. V komunálních volbách, jejichž podstata má nést prvek personalizace, neumožňují výzkum dostupná data - nelze zjistit, zda hlasy, které v celkovém součtu kandidát získal, byly uděleny voličem právě tomuto kandidátovi, nebo mu byly uděleny $\mathrm{v}$ důsledku označení celé stranické kandidátky. V ostatních typech voleb je dle názoru autorů koncept IA, jak je chápán v tomto článku, principiálně nepoužitelný, protože nelze měřit výhodu individuálních obhájců mandátu.

\section{Metody a data}

Cílem této studie je pomocí operacionalizovaného konceptu IA zjistit, zda v prostředí českých senátních voleb existuje výhoda pro obhájce senátorského mandátu. $\mathrm{Na}$ tomto místě je opět nutné připomenout, že celý koncept i jeho dosavadní operacionalizace se vztahuje téměř výlučně na americké volební prostředí, tedy na dvoustranický systém demokratů a republikánů (two-party vote), při užití jednokolového většinového volebního systému (první v cíli, FPTP). To s sebou prrináší, z hlediska zaměření práce, četná úskalí:

1. Operujeme ve vícestranickém prostředí (s možností nezávislé kandidatury), které je navíc značně proměnlivé ${ }^{12}$, proto nelze jednoduše převzít operacionalizaci, která využívá two-party vote.

${ }^{12}$ K vývoji stranického systému v České republice viz nap̌̌. Čaloud, Foltýn a Havlík 2006 a Havlík 2010. 
2. Máme co do činění s dvoukolovým volebním systémem - koncept nelze zcela přenést na první ( $z$ důvodu vícestranické povahy soutěže), ani na druhé kolo voleb (z důvodu množství subjektů postupujících do druhého kola). Česká varianta dvoukolového absolutně většinového volebního systémů obsahuje daleko více stimulů pro strategické chování stran, kandidátů i voličů než jednokolový relativně většinový systém, kterým se volí v USA. S volebním systémem souvisí i další dva důležité parametry, a to počet volebních obvodů a délka funkčního období. Zatímco volby do Sněmovny reprezentantů, které se většina literatury o výhodě obhájce týká, se konají každé dva roky (Dvořáková et al. 2008: 74), volby do Senátu v konkrétním volebním obvodě se v ČR konají po šesti letech. I to může mít na existenci výhody obhájce podstatný vliv. Důležitý je i počet volebních obvodů. Zatímco ve Spojených státech se volí ve 435 volebních obvodech, v České republice je jich při každých volbách pouze 27 , nebo i při součtu celého volebního cyklu jen 81 . To v první řadě přináší problémy s množstvím empirických dat, což může negativně ovlivnit reliabilitu daného měření.

3. Do druhého kola postupují zástupci různých subjektů, přičemž vítěz prvního kola nemusí být zároveň vítězem kola druhého - zvýšení podílu hlasů kandidáta nemusí znamenat vítězství ve volbách a $\mathrm{v}$ některých př́padech ani postup do druhého kola.

4. Senátní volby probíhají ve stranickém systému již zformovaném jiným typem volebního systému - jedná se o volby druhého řádu (viz Brtník a Havlík 2009: 134; Lebeda 2011: 247).

Všechny body představují výzvu pro zkoumání IA. Naše měření budou směřována především na první kolo voleb, jelikož ve druhém kole nejsme schopni relevantně měřit danou výhodu, protože zde působí celá řada faktorů, které ovlivňují rozhodování voličů a se kterými výše uvedené koncepty a metody nepočítají (např. vyjádření volební podpory nepostupujícího kandidáta).

Pro účely této práce budou využity oba výše definované koncepty (Gelman a King 1990), sophomore surge a retirement slump. Zjišt'ován bude nárůst hlasů kandidátů, kteři obhajují post, ve srovnání s obdobím, kdy obhájci mandátu nebyli, a také pokles hlasů pro stranu, jejíž obhájce již nekandiduje. První senátní volby se uskutečnily v roce 1996 a funkční období je stanoveno na šest let. To znamená, že pracujeme s osmi řádnými termíny voleb, kdy můžeme sledovat existenci IA, prričemž pro jednoho kandidáta je zde možnost maximálně tří znovuzvolení. Nemusíme se zabývat problematikou term limits, která je častým předmětem sporů autorů věnujících se americkým legislativním volbám (SS i RS budou užity pro všechny volby, nejen v prŕípadech prvního pokusu o znovuzvolenî). Na rozdíl od Gelmana a Kinga však nebude výpočet SS a RS modifikován pro jednotlivé strany, ale bude vždy využit základní zpo̊sob výpočtu pro každou stranu v daných volbách zvlášt’. Respektujeme pritom kritiku obou 
konceptů, především hledisko času, nicméně z výše uvedených důvodů ji lze opomenout. Výpočet bude prováděn vždy pro každé volby zvlášt’.

$$
\begin{aligned}
\mathrm{SS} & =\Sigma\left(\mathrm{v}_{2}-\mathrm{v}_{1}\right) / \mathrm{n} \\
\mathrm{RS} & =\Sigma\left(\mathrm{v}_{1}-\mathrm{v}_{2}\right) / \mathrm{n},
\end{aligned}
$$

kde $\mathrm{v}_{2}$ je volební výsledek kandidáta dané strany ve volbách $2, \mathrm{v}_{1}$ je volební výsledek kandidáta dané strany ve volbách 1 a n je počet kandidátů dané strany. Výpočty budou provedeny pro každou stranu zvlášt', přičemž rozlišujeme celkem šest kategorií, a to ODS, ČSSD, KSČM, KDU-ČSL, Ostatní ${ }^{13}$ a Změna stranické př́slušnosti ${ }^{14}$. Rozdělení výpočtů dle výše uvedených kategorií si klade za cíl zpřehlednit zisky jednotlivých stran $\mathrm{v}$ senátních volbách. V př́padě kategorií 3,5 a 6 je přitom výpovědní hodnota zkreslená malým počtem obhájců. SS a RS jsou následně vypočteny i pro dané volby jako celek. Obecně platí, že čím vyšší (kladné) číslo, tím vyšší je v daných volbách (pro danou stranu) výhoda obhájce.

Výše zmíněné měřící nástroje mají velkou nevýhodu v tom, že si nemůžeme být jisti, zda skutečně měři výhodu obhájce, či nikoliv, a to obzvláště v proměnlivém vícestranickém systému, jaký máme v ČR. Pokud by např́klad ve volbách 1 strana A získala ve všech obvodech $50 \%$ hlasů a ve volbách 2 stejní kandidáti dostanou ve všech obvodech $75 \%$, zjistíme, že průměrný nárůst u obhájce bude $25 \%$, což je velmi vysoká hodnota. Je ale samožrejmě možné, že by stejná strana získala ve volbách 2 ve všech obvodech $75 \%$ hlasů i v prípadě, že by kandidovali noví kandidáti. Stejně tak pokles u odcházejících kandidátů může sice indikovat výhodu obhájce, může ale znamenat pouze to, že politická strana ztratila podporu na celém území, nebo to, že se v obvodu objevil velmi silný protikandidát apod. Proto jsme se pokusili sestrojit výpočet indexu (I), který by alespoň částečně mohl výše zmíněné nedostatky zmírnit. Jelikož v České republice nemůžeme využít měřící nástroje popsané výše, které se vztahují výlučně k systémům dvou stran, a to navíc takovým, které nejsou proměnlivé, je náš index zaměřen vždy na výsledky kandidátů jedné konkrétní politické strany ve dvou po sobě jdoucích volbách. Tento př́stup má výhodu zejména v tom, že by sestrojený index měl být odolný vůči změnám ve volební podpoře jednotlivých stran, protože nesrovnává celkové volební výsledky politických stran, jejichž proměnlivost může být samozřejmě způsobená velkým množstvím námi nesledovaných faktorů, ale jednotlivých kandidátů uvnitř dané strany. Snažíme se zaměřit čistě na to, zda existuje rozdíl mezi tím, jakých volebních výsledků dosahuje politická strana $\mathrm{v}$ pŕípadech, kdy v obvodech kandidují obhájci mandátu, a v př́padech, kdy se voleb účastní ostatní kandidáti.

13 Typicky ODA, US-DEU či nezávislí kandidáti. V př́padě Čtyřkoalice je vždy zjištěna stranická př́slušnost kandidáta a připočtena $\mathrm{k}$ př́slušné kategorii.

${ }_{14}$ Jedná se $\mathrm{o}$ změnu stranické př́slušnosti mezi volbami $\mathrm{t}$ a $\mathrm{t}+1$, přičemž nejčastěji se jedná $\mathrm{o}$ prípady po rozpadu Čtyřkoalice. 


$$
I=\left(\sum_{\text {obhajci }} \frac{p_{2}}{p_{1}} \div N_{o}\right)-\left(\sum_{\text {kandidati }} \frac{p_{2}}{p_{1}} \div N_{k}\right)
$$

$\mathrm{V}$ tomto indexu budeme počítat rozdíl mezi aritmetickými průměry podílu hlasů ve volbách 2 a volbách 1 , a to zvlášt' u obhájců a u ostatních kandidátů téže strany. ${ }^{15}$ Protože tento index vyžaduje, aby strana měla ve volbách vždy alespoň jednoho obhajujícího kandidáta, budeme jej počítat pouze pro dvě v senátních volbách dlouhodobě nejúspěšnější strany, a to ODS a ČSSD. Rozdíl by potom měl být kladný, pokud výhoda obhájce existuje, a záporný, pokud nikoliv. Čím vyšší bude kladná hodnota indexu, tím vyšší bude výhoda, čím nižší bude záporná hodnota indexu, tím vyšší bude př́padná nevýhoda. Určitou nevýhodou tohoto indexu může být to, že si nemůžeme být jistí, že rozdílné hodnoty u obhájců mandátu a ostatních kandidátů jsou způsobeny právě výhodou obhájce mandátu. Roli mohou samozřejmě hrát i jiné faktory a do určité míry i náhoda. Toto negativum je ale značně oslabeno tím, že index počítáme u dvou politických stran $\mathrm{v}$ osmi různých volbách. Celkově získáme 15 výsledných hodnot ${ }^{16}$ sestrojeného indexu, což již může podat nezkreslený obraz o tom, zda v rámci konkrétních politických stran existuje rozdíl mezi tím, jak si v senátních volbách vedou obhájci mandátu a ostatní kandidáti.

Budeme analyzovat volební data ze všech dosud konaných senátních voleb v ČR od roku 1998 do roku 2012. Drobným metodologickým problémem by se mohlo zdát konání doplňovacích senátních voleb. Nicméně vzhledem $\mathrm{k}$ tomu, že jejich konání je možné pouze v případě, že se uvolní mandát stávajícího senátora, je jasné, že v těchto volbách nikdy nebude obhájce kandidovat. Doplňovací volby můžeme $z$ analýzy vyloučit, samozřejmě je ale musíme brát $\mathrm{v}$ úvahu vzhledem $\mathrm{k}$ tomu, že vítěz doplňovacích voleb může $\mathrm{v}$ následujících řádných volbách kandidovat právě jako obhájce. Podobně z analýzy vyloučíme první senátní volby, které se konaly v roce 1996, jelikož se logicky ani v nich nemohl o mandát ucházet nikdo, kdo by byl zvoleným senátorem. Opět ale musíme brát v úvahu to, kdo v těchto volbách zvítězil, pro př́pad, kdy by se tito kandidáti jako obhájci mandátu ucházeli o zvolení v následujících volbách konaných v letech 1998, 2000 a 2002.

Z několika důvodů se zaměříme pouze na výsledky prvního kola senátních voleb. Druhé kolo je velmi specifické z hlediska nízké volební účasti a možnosti strategického chování stran, kandidátů i voličů, jak již bylo popsáno výše. Podle

15 Do první skupiny budou zařazeny ty př́ípady, kdy za stranu kandiduje ve volbách 2 ten samý kandidát, který předtím zvítězil ve volbách 1. Případy, kdy za stranu kandidují bud' jiní kandidáti, nebo stejný kandidát, který ale ve volbách 1 nezvítězil, budou zařazeny do druhé skupiny.

16 Pouze 15 hodnot získáme z toho důvodu, že za ČSSD ve volbách v roce 2010 nekandidoval žádný obhájce mandátu z voleb v roce 2004. 
našeho názoru by poté analýza dat z druhého kola nijak nepřispěla ke hledání odpovědi na výzkumnou otázku. Pokud byl kandidát zvolen a v následujících volbách nekandidoval, nebude chápán jako obhájce, ačkoli se mohl účastnit následných volebních klání. Obhájcem mandátu není chápán ani obhájce, který kandiduje ve volbách $\mathrm{t}+1 \mathrm{v}$ jiném volebním obvodě, než tomu bylo ve volbách $\mathrm{t}$. V práci budou využita data Českého statistického úřadu, který výsledky voleb zveřejňuje na serveru Volby.cz.

Nejprve u každých sledovaných voleb uvedeme základní informace, které nás zajímají, tzn. počet kandidujících obhájců a jejich úspěšnost, tedy zda vypadli v prvním kole, postoupili do druhého kola, či byli znovuzvoleni senátory. Tato deskriptivní analýza nám dá některé základní informace, nicméně ke zjištění, jestli existuje v senátních volbách výhoda obhájce, budeme muset využít jiných výše popsaných metod, a to výpočtu SS, RS a indexu I.

\section{Senát Parlamentu České republiky}

Otázka vzniku horní komory Parlamentu České republiky se stala předmětem dlouhé politické diskuze první poloviny 90. let. První volby do horní komory proběhly až v roce 1996, tři roky po vzniku samostatné České republiky. Česká zákonodárná moc je založena na asymetrickém bikameralismu, prričemž Poslanecká sněmovna má silnější postavení na úkor Senátu. Senát je konstruován více jako stabilizující a kontrolní činitel (více viz Filip 1997).

Český Senát čítá 81 senátorů, kteří jsou voleni na dobu šesti let, přičemž každé tři roky dochází $\mathrm{k}$ obměně jedné třetiny členů (tj. 27). ${ }^{17}$ Pasivní volební právo je stanoveno na 40 let. Kandidáty pro volbu do Senátu mohou přihlašovat registrované politické strany, politická hnutí, jejichž činnost nebyla pozastavena, a koalice. Nezávislý kandidát podává prrihlášku $\mathrm{k}$ registraci sám (Zákon č. 247/1995 Sb.).

Volby do Senátu se v českém prostředí vedle voleb prezidentských konají za principu většinového volebního mechanismu, a to absolutního dvoukolového (viz Chytilek et al. 2009: kapitola 3). Daný typ volebního systému vyžaduje, aby byl v obvodě (území ČR je pro senátní volby rozděleno do 81 jednomandátových volebních obvodů) zvolen kandidát, který získá absolutní většinu hlasů zúčastněných voličů. Dvoukolový systém umožňuje zvolení kandidáta již v prvním kole, a to $\mathrm{v}$ českém prostředí za předpokladu zisku nadpoloviční většiny hlasů. Pokud danou podmínku žádný kandidát nesplní, následuje druhé kolo, do něhož (opět $\mathrm{v}$ českém prípadě) postupují první dva kandidáti $\mathrm{z}$ kola předešlého jedná se o variantu uzavřeného druhého kola, někdy také označovanou jako tzv.

17 Doplňovací volby se konají $\mathrm{v}$ případě, že zanikne $\mathrm{v}$ průběhu volebního období mandát stávajícího senátora. Nově zvolený senátor je v př́padě doplňovacích voleb zvolen pouze na zbytek doby mandátu svého předchůdce. 
prezidentský dvoukolový systém (Sartori 2001: kapitola 1.5), nebo majority runoff systém (Farrell 2001: 51-52). Díky tomu existuje naprostá jistota, že jeden $z$ kandidátů získá nadpoloviční většinu hlasů. $\mathrm{V}$ př́ípadě rovnosti hlasů rozhoduje los (Zákon č. 247/1995 Sb.).

Nestává se velmi často, aby byl zvolen kandidát již v prvním kole voleb (od roku 1996 k tomu v českých senátních volbách došlo pouze devětkrát), což znamená, že volič musí k volbám dvakrát. Dvoukolový většinový systém je ve své podstatě dvěma po sobě se opakujícími volbami. ${ }^{18}$ Stanovený interval mezi prvním a druhým kolem je v českých senátních volbách stanoven na nejpozději šestý den po ukončení kola prvního a slouží jak politickým stranám k vyjednávání o podpoře, ${ }^{19}$ tak voličům pro nové rozhodnutí, komu odevzdají svůj hlas (Sartori 2001: 75-76). Cox (1997: 123-138) tvrdí, že v případě uzavřeného dvoukolového systému pouze tři nejúspěšnější kandidáti mají šanci na výraznou volební podporu. $^{20}$

Vedle přímé volby hlavy státu jsou senátní volby nejvíce personalizovaným kláním, což s sebou přináší i větší důraz na individuální charakteristiky kandidátů (personalizaci voleb). Strategické účinky dvoukolového volebního systému v českých senátních volbách do jisté míry zpochybnil Roman Chytilek (2005a: 107-109, 2005b: 21). Ten poukázal na to, že v českém prostředí existuje několik faktorů, kvůli nimž je interakce politických stran mezi prvním a druhým kolem voleb velmi slabá a pokud probíhá, tak spíše na úrovni volebních obvodů nebo jednotlivých kandidátů. Jednotlivé faktory, které tento jev způsobují, jsou zejména snížená ochota voličú účastnit se druhého kola, slabá voličská loajalita a to, že strany neznají ordinální preference svých voličů.

Slabší strategické účinky volebního systému do Senátu předpokládá i Tomáš Lebeda: když do druhého kola postupují pouze dva soupeři, není už prakticky s kým a o čem jednat. Postupující kandidáti se mohou maximálně obrátit na ty, kteří se do druhého kola nedostali, aby vybídli své voliče $\mathrm{k}$ jejich podpoře (Lebeda, Malcová a Lacina 2009: 246). Martin Kreidl (2009) zkoumal chování voličů v prvním kole českých senátních voleb se zaměřením na vlastnosti kandidátů. V ČR platí, že voliči obvykle volí podle stranického principu a klíčovou úlohou při rozhodování má stranická identifikace, př́padně shoda vlastní politické

\footnotetext{
18 Nicméně logika obou kol se zásadně liší, jelikož první kolo $\mathrm{v}$ naprosté většině případů představuje pouze selekci kandidátů. Skutečnou volbu - elekci - přináší až kolo druhé. První kolo většinou zpř̌ehledňuje situaci - plní úlohu selekce. Skutečná volba - elekce - následuje až v kole druhém (viz Sartori 2001).

19 To je však případ především dvoukolových mechanismů s otevřeným druhým kolem $\mathrm{v}$ prípadech, kdy postupuje více kandidátů.

${ }^{20}$ Jedná se o počet kandidátů postupujících do druhého kola plus jedna. Strategické hlasovaní je v prvním kole uzavřeného dvoukolového systému podle Coxe podobně častým jevem jako v prostředí jednokolového systému, byt' má poněkud jinou podobu. Netvoři se zde dualita silných kandidátů, ale trojice silných kandidátů (Cox 1997: 128).
} 
ideologie s ideologií strany. Nicméně specifické vlastnosti samotných kandidátů (věk, pohlaví, zaměstnání, ...) mohou přinášet dostatečný zisk a/nebo ztrátu hlasů ve srovnání s preferencemi volební strany, a to zejména nerozhodnutých voličů (Kreidl 2009: 111). ${ }^{21}$

\section{Incumbency advantage v českých senátních volbách}

Diskuze ohledně výhody obhájce vychází z prostředí americké politické reprezentace. Jedná se o faktory jako mediální známost, schopnost distribuovat různé klientelistické benefity do svých obvodů atp. I přesto, že tyto výhody ve své „pravéc podobě nelze v českém prostředí sledovat v takové míře jako ve Spojených státech amerických, ${ }^{22}$ obhájci senátorského mandátu přesto mohou odkazovat na již odvedenou práci v Senátu, jejich jméno je mezi voliči známé již jen díky tomu, že zvítězili v předchozích volbách. Obhájci mandátu mají z pozice senátorů snadnější prúístup do médií či $\mathrm{k}$ finančním i lidským zdrojům (a to jak uvnitř strany, za kterou kandidují, tak mimo tuto stranu), z čehož usuzujeme přeci jen značné potenciální výhody obhájců oproti vyzyvatelům. Přestože koncept IA není v českých podmínkách prozatím přiliš využívaný, není ani zcela neznámý a držení mandátu bylo některými texty i v českých podmínkách označeno za významnou individuální charakteristiku kandidátů.

Napřr. Tomáš Lebeda při zkoumání příčiny nárůstu či poklesu volební podpory kandidátů mezi prvním a druhým kolem zahrnul do svého výzkumu i některé individuální charakteristiky kandidátů (Lebeda 2011: 260-261). Jako nejsilnější determinant se prokázal rozdíl mezi volební účasti mezi prvním a druhým kolem (viz Tabulka č. 1), nás však především zajímá proměnná senátor, kdy Tomáš Lebeda zkoumal, jaký vliv má na změnu volební podpory to, že jeden z kandidátů je obhájcem senátorského postu. Je nutné zmínit, že byl zkoumán rozdíl v podpoře mezi prvním a druhým kolem. To znamená, že byl zkoumán v podstatě jiný jev než ten, který je předmětem naší analýzy. Přestože výsledky nebudeme moci srovnávat, jsou zjištění z výzkumu zajímavá. Obhajoba senátorského postu se totiž ukázala být jako nevýhoda, což Tomáš Lebeda vysvětluje tím, že ve druhém kole se hlasy voličù sjednotí proti stávajícímu

21 Z Kreidlova výzkumu vyplývá, že ideálním kandidátem na post senátora (který by měl bez ohledu na stranickou afilaci největší šanci na zvolení u „průměrného“ voliče) je muž nebo žena ve věku 50-59 let, s titulem profesor nebo docent a bydlící na území volebního obvodu, kde kandiduje. Tomáš Lebeda (2011: 260) specifikuje, že ve druhém kole je výhodou lékařská profese, přesněji řečeno lékařský titul MUDr.

${ }^{22}$ Regionální média, která by sledovala výkon „svých“ senátorů, téměř neexistují, co činí senátor v průběhu svého mandátu, se volič většinou nedozví. Dále senátoři, vzhledem k postavení horní komory v politickém systému České republiky, na rozdíl od poslanců nemohou príliš ovlivnit zákony tak, aby poskytovali partikularistické výhody svým obvodům, nebo konkrétním podporovatelům. Práce a funkce Senátu je pro občany nečitelná a nesrozumitelná, celkově voliči nemají o fungování Senátu príliš zájem, což se projevuje i velmi nízkou volební účastí. 
senátorovi, zatímco naopak $\mathrm{v}$ prvním kole jsou hlasy rozptýlené mezi několik vyzyvatelů a roli hraje i známost dosavadního senátora (Tamtéž: 260). Okrajově Tomáš Lebeda předpokládá to, že v prvním kole voleb by mohla existovat výhoda obhájce mandátu.

Tabulka č. 1: Volební účast v českých senátních volbách

\begin{tabular}{|c|c|c|c|c|c|c|c|c|c|c|}
\hline Rok & 1996 & 1998 & 2000 & 2002 & 2004 & 2006 & 2008 & 2010 & 2012 & Průměr \\
\hline 1. kolo & 35,03 & 42,37 & 33,72 & 24,1 & 28,97 & 42,09 & 39,52 & 44,59 & 34,9 & 36,14 \\
\hline 2. kolo & 30,63 & 20,36 & 21,56 & 32,55 & 18,41 & 20,73 & 29,85 & 24,64 & 18,6 & 24,15 \\
\hline
\end{tabular}

Zdroj: volby.cz

Koncept výhody obhájce ve svých textech využili také Josef Bernard (2012) a velmi okrajově Dan Ryšavý (2010), oba ale zkoumali problematiku komunálních voleb. Josef Bernard zkoumal ve svém regresním modelu to, do jaké míry proměnné obhajování mandátu, politický subjekt, pohlaví, věk, tituly, číslo na kandidátce a úspěšnost kandidátky ovlivňují šanci na zisk mandátu u jednotlivých kandidátů (Bernard 2012: 630-635). Došel k závěru, že vůbec nejsilnějším individuálním faktorem u kandidátů byla právě obhajoba mandátu (Tamtéž: 636). Ta umožnila kandidátům jak postavení na předních místech kandidátek, tak posléze pozitivně působila na jejich podporu u voličů. $\mathrm{K}$ podobným závěrům došel i Jakub Šedo (2009: 359).

Z Tabulky č. 2 můžeme vyčíst základní informace o úspěšnosti obhájců mandátu v senátních volbách v ČR. Co se týká počtu kandidujících obhájců, ten se s výjimkou roku 2004 pohyboval vždy mezi 17 a 20, což značí poměrně setrvalý stav, nemůžeme ani zaznamenat žádný trend poklesu nebo růstu počtu kandidujících obhájců. Pouze ve zmíněném roce 2004 kandidovalo pouze 14 stávajících senátorů, což je pouze polovina kandidátů, kteří v roce 1998 získali mandát. To bychom mohli zřejmě částečně vysvětlit úspěchem Čtyřkoalice v senátních volbách v roce 1998,,$^{23}$ která získala 13 mandátů, príčemž stranické spektrum se právě v době od roku 1998 do roku 2004 značně proměnilo (Čaloud, Foltýn a Havlík 2006). Podobně bychom mohli vysvětlit i druhý nejnižší počet kandidujících obhájců v roce 2006.

${ }^{23}$ Kompletní volební výsledky voleb do Senátu viz v Tabulce č. 3. 
Tabulka č. 224: Úspěšnost obhájců mandátů v senátních volbách

\begin{tabular}{|c|c|c|c|c|c|c|c|c|c|c|}
\hline \multirow{2}{*}{ Volby } & \multirow{2}{*}{$\begin{array}{l}\text { Celkem } \\
\text { soutěží }\end{array}$} & \multicolumn{2}{|c|}{$\begin{array}{c}\text { Kandidovalo } \\
\text { obhájců }\end{array}$} & \multicolumn{2}{|c|}{$\begin{array}{l}\text { Vypadli v } 1 . \\
\text { kole }\end{array}$} & \multicolumn{2}{|c|}{ Prohráli ve 2 . kole } & \multicolumn{3}{|c|}{ Vítězové } \\
\hline & & Počet & $\%$ & Počet & $\%$ & Počet & $\begin{array}{c}\% \\
\text { z postupujících }\end{array}$ & Počet & $\begin{array}{c}\% \\
\text { z obhájců }\end{array}$ & $\begin{array}{c}\% \text { v } 2 . \\
\text { kole }\end{array}$ \\
\hline 1998 & 27 & 19 & 70,37 & 2 & 10,53 & 5 & 29,41 & 12 & 63,16 & 70,59 \\
\hline 2000 & 27 & 20 & 74,07 & 7 & 35 & 7 & 53,85 & 6 & 30 & 46,15 \\
\hline 2002 & 27 & 17 & 62,96 & 4 & 23,53 & 7 & 53,85 & 6 & 35,29 & 46,15 \\
\hline 2004 & 27 & 14 & 51,85 & 2 & 14,29 & 7 & 58,33 & 5 & 35,71 & 41,67 \\
\hline 2006 & 27 & 17 & 62,96 & 4 & 23,53 & 5 & 38,46 & 8 & 47,06 & 61,54 \\
\hline 2008 & 27 & 20 & 74,07 & 5 & 25 & 10 & 66,67 & 5 & 25 & 33,33 \\
\hline 2010 & 27 & 20 & 74,07 & 4 & 20 & 10 & 62,5 & 6 & 30 & 37,5 \\
\hline 2012 & 27 & 19 & 70,37 & 8 & 42,11 & 3 & 27,27 & 8 & 42,11 & 72,73 \\
\hline
\end{tabular}

Zdroj: vlastní tabulka; data volby.cz

Postup do 2. kola byl u obhájců častou záležitostí, výjimkou jsou zejména volby v letech 2000 a 2012, což se opět můžeme pokusit vysvětlit proměnami stranického systému. Oběma zmiňovaným volbám předcházely volby (roky 1996 a 2006), v nichž víceméně dominovaly obě nejsilnější strany, zatímco volby v letech 2000 a 2012 jsou charakteristické úspěchem Čtyřkoalice, resp. nových stran a nezávislých kandidátů (Balík et al. 2013: 68-80). Počet vítězných obhájců je jednoznačně nejvyšší (relativně i absolutně) ve volbách v roce 1998, kdy zvítězilo hned 12 obhájců. Tentokrát je podle nás možným vysvětlujícím faktorem zejména čas, jelikož pro obhájce mandátu bude výhodné, pokud je mezi volbami období pouhých dvou let, než pokud mandát senátora trvá celých šest let. Za prvé budou tito obhájci známější mezi voliči, za druhé za tuto dobu nemůže dojít k velké proměně systému stran.

${ }^{24} \mathrm{~V}$ tabulce není uveden rok 1996, jelikož se jednalo o první konané senátní volby, a tudíž v nich nemohl kandidovat obhájce. $V$ tabulce jsou zahrnuti i obhájci, kteří byli zvoleni v doplňovacích volbách (platí i pro další tabulky). 
Tabulka č. 3: Zisky mandátů jednotlivých stran v senátních volbách

\begin{tabular}{|l|c|c|c|c|c|c|c|c|c|c|c|}
\hline \multicolumn{1}{|c|}{ Strana } & 1996 & 1998 & 2000 & 2002 & 2004 & 2006 & 2008 & 2010 & 2012 & Doplňovací & Celkem \\
\hline ODS & 32 & 9 & 8 & 9 & 18 & 14 & 3 & 8 & 4 & 2 & 107 \\
\hline ČSSD & 25 & 3 & 1 & 7 & 0 & 6 & 23 & 12 & 13 & 2 & 92 \\
\hline KSČM & 2 & 2 & 0 & 1 & 1 & 0 & 1 & 0 & 1 & 1 & 9 \\
\hline KDU-ČSL & 13 & 0 & 0 & 1 & 3 & 4 & 0 & 2 & 2 & 3 & 28 \\
\hline Čtyřkoalice & 0 & 13 & 17 & 0 & 0 & 0 & 0 & 0 & 0 & 0 & 30 \\
\hline Ostatní & 8 & 0 & 0 & 8 & 5 & 2 & 0 & 5 & 5 & 0 & 33 \\
\hline NK & 1 & 0 & 1 & 1 & 0 & 1 & 0 & 0 & 2 & 1 & 7 \\
\hline Celkem & 81 & 27 & 27 & 27 & 27 & 27 & 27 & 27 & 27 & 9 & 306 \\
\hline
\end{tabular}

Zdroj: vlastní tabulka; data volby.cz

Existuje v českých senátních volbách výhoda obhájce? Připomeňme, že výpočty jsou provedeny pouze na prvním kole senátních voleb a výpočet SS není omezen jen na první pokus o znovuzvolení. Klíčovým ukazatelem při hledání odpovědi na otázku, zda v prostředí českých senátních voleb lze hovořit o IA, je Tabulka č. 4. Celkové podíly hlasů pro obhájce se při pokusech o znovuzvolení nezvyšují, neboli všechny hodnoty SS nabývají záporných hodnot. V tomto prípadě můžeme mluvit spíše o nevýhodě zastávání úřadu, podobně jako Tomáš Lebeda (2011). V průměru došlo k poklesu o 5,52 \% hlasů.

Tabulka č. 4: Průměr nárůstu (SS) a poklesu (RS)

\begin{tabular}{|c|c|c|c|c|c|c|c|c|}
\hline Rok & 1998 & 2000 & 2002 & 2004 & 2006 & 2008 & 2010 & 2012 \\
\hline SS & $-3,55$ & $-9,06$ & $-1,81$ & $-2,43$ & $-3,37$ & $-4,22$ & $-9,74$ & $-9,95$ \\
\hline RS & 4,89 & 12,67 & 1,07 & 9,07 & 4,93 & 1,65 & 9,81 & 10,84 \\
\hline
\end{tabular}

Zdroj: vlastní tabulka; data volby.cz

Záporné hodnoty převažují nad kladnými i v Tabulce č. 5, tedy v hodnotách měrených pro jednotlivé strany (kategorie). Tato data jsou však pouze dílčím ukazatelem, jelikož mohou být značně problematická, a to v př́padě, kdy hodnoty vznikly na základě výsledků jediného obhájce. Tento fakt výrazně snižuje výpovědní hodnotu dílčích dat, i přesto však nejsou zcela neužitečná. Např. v hodnotách SS je zajímavé si povšimnout hodnot 12,12 (KDU-ČSL v roce 2000), kterou lze vysvětlit úspěchem projektu Čtyřkoalice, či 10,80 (ODS v roce 2006), která je pravděpodobně dána rokem konání (ve stejném roce $\mathrm{v}$ červnu zvítězila ODS ve volbách do Poslanecké sněmovny; senátní volby následovaly v říjnu). 
Tabulka č. 5: Nárůst (SS) a pokles (RS) jednotlivých stran ${ }^{25}$

\begin{tabular}{|c|c|c|c|c|c|c|}
\hline \multirow{2}{*}{ Rok } & \multicolumn{2}{|c|}{ ODS } & \multicolumn{2}{|c|}{ ČSSD } & \multicolumn{2}{|c|}{ KSČM } \\
\hline & SS & RS & SS & RS & SS & RS \\
\hline 1998 & $-11,34$ & 7,08 & $-3,1$ & 3,44 & & \\
\hline 2000 & $-18,53$ & 15,27 & $-4,93$ & 7,49 & $10,34^{*}$ & \\
\hline 2002 & $-11,54$ & 9,93 & 1,82 & 1,49 & & $-0,63 *$ \\
\hline 2004 & 6,26 & 1,65 & & 12,16 & 3,02 & \\
\hline 2006 & 10,8 & $-7,22$ & & $-1,25^{*}$ & & \\
\hline 2008 & $-9,72$ & 2,21 & 13,09 & $-3,31$ & $-11,85^{*}$ & \\
\hline 2010 & $-11,34$ & 8,68 & & & & \\
\hline 2012 & $-17,32$ & 17,08 & 0,65 & $-1,7^{*}$ & $1,34^{*}$ & \\
\hline & $\mathrm{KD}$ & SLL & Ost & & $\begin{array}{r}\text { Změna } \\
\text { př́íslu }\end{array}$ & $\begin{array}{l}\text { inické } \\
\text { osti }\end{array}$ \\
\hline & SS & RS & SS & RS & SS & RS \\
\hline 1998 & 9,61 & & 6,73 & & 0,63 & \\
\hline 2000 & 8,45 & & & & $-19,23$ & \\
\hline 2002 & $-8,79$ & $-7,56$ & & & 12,24 & \\
\hline 2004 & $-7,76$ & 20,1 & & $7,47^{*}$ & $-12,04$ & \\
\hline 2006 & $-13,72$ & 14,51 & $-21,56^{*}$ & $16,23^{*}$ & $-10,68$ & \\
\hline 2008 & $-0,85$ & $14,89 *$ & $-4,26$ & & $-15,94$ & \\
\hline 2010 & & 12,08 & $2,13^{*}$ & & $-7,58$ & \\
\hline 2012 & $3,27 *$ & 4,66 & $-7 *$ & & $-14,95$ & \\
\hline
\end{tabular}

Zdroj: vlastní tabulka; data volby.cz

Naopak kladné hodnoty pozorujeme u výpočtu průměru RS, tedy poklesu podílu hlasů pro strany, jejichž senátor v daných volbách nekandidoval a strana musela nominovat nového kandidáta, a to ve všech senátních volbách (v dílčích výsledcích nabývají zápornou hodnotu RS pouze tři případy). Průměrný pokles ve sledovaných volbách činil 6,87 \% hlasů. Tuto skutečnost lze interpretovat tak, že strana skutečně trpí ztrátou tehdy, pokud odstupuje senátor a strana musí nominovat nového kandidáta. Jestliže se zaměříme na dílčí data, lze např. hodnotu -7,56 (KDU-ČSL v roce 2002) opět vysvětlit působením projektu Koalice (slučování subjektů i pokles popularity), nebo hodnotu -7,22 u ODS v roce 2006 tak, že je pravděpodobně dána úspěchem strany $\mathrm{v}$ tomto volebním roce $\mathrm{i}$ ve

$25 *$ značí hodnotu, kterou představuje SS/RS jednoho jediného kandidáta; platí i pro následující tabulky. 
volbách prvního řádu. Nicméně obecně nelze hovořit o výhodě obhájce, jelikož teorie předpokládá, že hodnoty SS i RS budou kladné.

Jako poslední jsme zjišt'ovali hodnoty námi sestrojeného indexu, který porovnával zisky jednotlivých kandidátů určité strany, konkrétně ČSSD a ODS, v závislosti na tom, zda se jednalo o obhájce mandátu, nebo nikoliv. U ODS dosáhl index kladných hodnot, které by poukazovaly na určitou výhodu obhájců mandátu, jen ve dvou prípadech, a to v letech 1998 a 2012. V ostatních př́padech došlo vždy $\mathrm{k}$ tomu, že ODS v porovnání dvou po sobě jdoucích voleb více získávala, nebo méně ztrácela ${ }^{26}$ tam, kde naopak obhájci mandátu nekandidovali. Podobě tomu bylo i u ČSSD, kde index nabyl kladných hodnot opět jen ve dvou pŕípadech, a to v letech 2004 a 2006. V následujících volbách v roce 2008 ale index dosáhl vůbec nejnižší naměřené hodnoty $(-0,53)$ a zápornou hodnotu měl index $\mathrm{i}$ v posledních sledovaných volbách v roce 2012. Výpočet indexu pro rok 2010 u ČSSD chybí z toho důvodu, že v tomto roce za ČSSD nekandidoval žádný obhájce mandátu.

Ani tyto hodnoty existenci výhody obhájce nijak neprokázaly. Celkové hodnoty indexu vyšly u obou námi sledovaných stran záporně, kladných hodnot bylo dosaženo jen dvakrát u obou stran. Výpočet nemůžeme brát jako úplně průkazný, jelikož pozice obhájců může být ztížená tím, že jako silní kandidáti získají vysoký podíl hlasů již v prvních volbách a prostor pro nárůst hlasů ve volbách následujících je malý. Naopak pokud v určitém obvodě kandidoval slabý kandidát, je zde $\mathrm{v}$ prrípadě nasazení silného kandidáta $\mathrm{v}$ prrístích volbách daleko větší prostor pro relativní zvýšení počtu hlasů než v obvodě, v němž kandiduje silný obhájce. Vzhledem k poměrně vysokému počtu vypočítaných indexů (15) a v kombinaci s dalšími použitými metodami si ale již mưžeme udělat základní přehled o tom, zda výhoda obhájců mandátu v českých senátních volbách skutečně existuje. Námi vypočítané hodnoty tomu př́liš nenasvědčují.

Tabulka č. 6: Individuální vs. stranická výhoda obhájce mandátu

\begin{tabular}{|c|c|c|c|c|c|c|c|c|c|c|}
\hline \multicolumn{2}{|c|}{ Volby } & 1998 & 2000 & 2002 & 2004 & 2006 & 2008 & 2010 & 2012 & Průměr \\
\hline \multirow{3}{*}{ ODS } & obhájci & 0,94 & 0,58 & 0,72 & 1,17 & 1,4 & 0,75 & 0,7 & 0,55 & 0,85 \\
\cline { 2 - 12 } & ostatní & 0,75 & 0,65 & 0,88 & 1,21 & 1,45 & 1,01 & 0,72 & 0,5 & 0,9 \\
\cline { 2 - 12 } & index & 0,19 & $-0,07$ & $-0,16$ & $-0,04$ & $-0,05$ & $-0,26$ & $-0,02$ & 0,05 & $-0,05$ \\
\hline \multicolumn{10}{|c|}{} \\
\hline \multirow{2}{*}{ ČSSD } & obhájci & 0,91 & 0,81 & 1,09 & 0,73 & 0,61 & 1,53 & $\mathrm{X}$ & 1,1 & 0,97 \\
\cline { 2 - 12 } & ostatní & 1,03 & 0,9 & 1,3 & 0,61 & 0,46 & 2,06 & $\mathrm{X}$ & 1,28 & 1,09 \\
\cline { 2 - 11 } & index & $-0,12$ & $-0,09$ & $-0,21$ & 0,12 & 0,15 & $-0,53$ & $\mathrm{X}$ & $-0,18$ & $-0,11$ \\
\hline
\end{tabular}

Zdroj: vlastní tabulka

${ }^{26}$ Jsou-li hodnoty indexu záporné, strana oproti minulým senátním volbám ztratila podporu, a naopak, jsou-li hodnoty kladné, straně se podpora zvýšila. 


\section{Pokus o vysvětlení}

Ačkoliv výsledky našeho výzkumu nejsou v souladu s teoretickými předpoklady, které jsme nastínili $\mathrm{v}$ úvodních kapitolách, do značné míry je to očekávatelné a vysvětlitelné, a to $z$ několika důvodů. Za prvé, jak již bylo podrobněji popsáno výše, pochází naprostá většina dosavadních prací o konceptu IA ze Spojených států amerických. Výsledky dosavadních výzkumů jsme sice mohli brát jako určitý úvodní materiál pro náš výzkum, nicméně vzhledem k odlišnosti obou politických systémů je přenositelnost teorie na českou politickou realitu značně obtížná. Za druhé, náš výzkum je prvním pokusem komplexněji se touto problematikou v českém prostředí zabývat. Proto je samozřejmě možné a žádoucí, aby vzniky i další práce s podobným tématem, mapující např́iklad jiné volby, soustředící se podrobněji na vybranou volební soutěž či užívající jiné metody, např́klad zmíněnou regresní analýzu. Vhodným doplněním výzkumů prováděných na základě agregovaných dat by jistě byly i výzkumy, které by danou problematiku zkoumaly z jiných perspektiv, a to zejména z pohledu samotných voličů.

Za třetí, i v literatuře zabývající se politickými systémy střední a východní Evropy můžeme nalézt teorie, které by námi zjištěný jev, určitou nevýhodu u kandidáta, který obhajuje mandát, dokázaly vysvětlit. Jednu z takových teorií předložil ve své nedávné práci týkající se kvality demokracie ve střední a východní Evropě Andrew Roberts (2010). Ten se zabýval jevem, který nazval jako volební odpovědnost stran. Zkoumal, jestli existuje vztah mezi tím, jak úspěšně působí obhájci mandátu ve svých volených funkcích a tím, jaký je následně jejich volební výsledek. Klíčem k odpovědi na tuto otázku je samozřejmě to, zda, a případně jak, působení obhájců v úřadě reflektují voliči, zda neúspěšné trestají a úspěšné naopak odměnují (Roberts 2010: 51-52). Jak ale zjistit, který politik byl v úřadě úspěšný a který nikoliv? Zde Roberts z několika důvodů předpokládá primární hodnocení na základě ekonomických proměnných, jako jsou míra inflace, nezaměstnanost a ekonomický růst, tedy př́pady, kdy volič pravděpodobněji odevzdá svůj hlas obhájci mandátu, pokud je ekonomická situace podle určitých objektivních kritérií dobrá. ${ }^{27}$ Nicméně roli mohou hrát i dalši témata jako korupce nebo nesplněné předvolební sliby (Tamtéž: 53-54).

Výsledky analýzy př́nesly poměrně zajímavá data. ${ }^{28}$ Téměř ve všech př́padech došlo $\mathrm{k}$ tomu, že vládním stranám poklesl podíl hlasů oproti volbám předcházejícím, a $\mathrm{v}$ mnoha př́padech byl tento propad velmi významný (Tamtéž: 59). Andrew Roberts došel k závěru, že voliči rozlišují mezi obhájci a opozicí a že silněji ve volbách trestají právě obhájce mandátu. Protože ale voliči trestaji téměř všechny obhájce, lze toto vysvětlit na základě předpokladů, že voliči dobře pracující politiky odmění a špatně pracující potrestají? Částečně ano, když jako

${ }^{27}$ Viz teorie retrospektivní ekonomické volby např́klad v Lewis-Beck a Stegmaier 2000.

28 Analýza zkoumala data z Bulharska, České republiky, Estonska, Mad’arska, Lotyšska, Litvy, Polska, Rumunska, Slovenska a Slovinska od počátku tranzice po rok 2006 (Roberts 2010: 57-60). 
nevýznamnější proměnná se ukázal být vliv míry nezaměstnanosti, musíme ale vzít v úvahu i další faktory, jako je korupce (Tamtéž: 60-68).

Přesto, a to je pro nás důležité, výzkum ukázal, že téměř všechny vlády obhajující mandát ztratí hlasy. Některé více a některé méně, v závislosti na jejich výkonnosti, ale celkově je pro obhájce v oblasti střední a východní Evropy velmi složité udržet si podporu voličů, nebo ji ještě zvýšit. Ačkoliv se výzkum Andrewa Robertse zabýval odlišnou volební arénou a byl jinak vymezen i teritoriálně, shoda našich závěrů je poměrně zajímavá. Samotná podstata toho, proč vlastně voliči v regionu takto masivně univerzálně trestají obhájce, není úplně jasná. Jedná se o téma, které by si určitě zasloužilo další rozsáhlejší výzkum.

\section{Závěrem}

Koncept incumbency advantage se stal jedním z často diskutovaných témat americké politologické literatury zabývající se volebním chováním. Výhoda, kterou disponuji obhájci poslaneckých a senátorských mandátů byla přitom popisována pěti kategoriemi vysvětlení: vyšší kvalitou obhájců, obhajováním mandátu jako zkratkou ve volebním obvodě, scare-off výhodou, zvýšením výdajů ve volebním obvodě a name recognition. Ačkoli se autoři víceméně shodují v tom, jak výhoda obhájce vzniká, ožehavým tématem se stalo, jak ji měrit. Z tohoto úhlu pohledu je prritom nejcitovanější a nejužívanější operacionalizace Gelmana a Kinga z roku 1990, která však není zcela bezproblémová. Náš text přitom slouží jako jeden z prvních exkurzů do dané problematiky s aplikací na české senátní volby.

Jestliže koncept IA přejímáme pro české senátní volby, narážíme na významné problémy, které vyplývají z politického prostředí (dvoustranického systému a jednokolového většinového volebního systému), pro které byl celý koncept i jeho operacionalizace navrženy. Tato práce si nekladla za cíl tyto problémy vyřešit a přijít s novým způsobem měření IA, které by bylo vhodným metodologickým rámcem českých senátních voleb, tj. značně proměnlivého stranického systému a dvoukolového volebního systému (s prrihlédnutím na druhořadost voleb). Namísto toho přejímá měření nárưstu a poklesu podílů hlasů obhájců, přičemž nezastíráme omezenou výpovědní hodnotu získaných dat. $\mathrm{K}$ alespoň částečnému vysvětlení rozdílu mezi individuální a stranickou výhodou obhájce slouží užité porovnání průměrů podílů hlasů obhájců mandátu a ostatních kandidátů dané strany.

V souvislosti s IA v českých senátních volbách lze hovořit spíše o opačném efektu, o nevýhodě obhájců mandátu. Na základě analýzy dat jsme došli k závěru, že existenci výhody obhájce se prokázat nepodařilo. Je pravděpodobné, že na volební výsledky jednotlivých kandidátů v senátních volbách má větší vliv aktuální politická situace a podoba stranického systému, př́padně jiné individuální charakteristiky kandidátů, než to, zda kandidát obhajuje senátorský mandát, či nikoliv. 
$\mathrm{Na}$ druhou stranu se podařilo poměrně přesvědčivě prokázat jeden zajímavý fakt, a to ten, že v prípadě, kdy se obhájce mandátu rozhodne znovu nekandidovat, znamená toto jeho rozhodnutí většinou pokles podílu hlasů pro danou stranu. Tento fakt a zejména jeho př́ććiny by si jistě zasloužily podrobnější zpracování. Obecně nelze tento závěr rozvádět v tom smyslu, že kladné hodnoty RS ukazují na existenci výhody obhájců mandátu, jelikož dle teorie by obě hodnoty SS i RS měly být kladné, aby bylo možné o IA hovořit. Domníváme se ale, že se jedná o samo o sobě zajímavé zjištění, které nelze přičítat čistě náhodě.

Celkově tvrdíme, že na základě zvolených metod měření jsou naše závěry o existenci výhody obhájců mandátu v českých senátních volbách negativní. Pro definitivní potvrzení neexistence IA by ale bylo nutné sestrojit sofistikovanější metodu měření na bázi regresního modelu, který by umožňoval zahrnout vícestranickost a vícekolovost českých senátních voleb, snad s přihlédnutím $\mathrm{k}$ jejich charakteru voleb druhého řádu.

$\mathrm{Na}$ závěr jsme se pokusili vysvětlit, jaký by mohl být důvod toho, že obhájci mandátu jsou v českých senátních volbách spíše znevýhodněni, než aby samotný fakt toho, že jsou obhájci mandátu, byl jejich výhodou. $\mathrm{K}$ tomu jsme využili teorii retrospektivní ekonomické volby, která říká, že voliči ve volbách odměňují či trestají obhájce mandátu za jeho výkon $\mathrm{v}$ úřadě $\mathrm{v}$ předcházejícím volebním období. Poukázali jsme také na to, že podle předchozího výzkumu Andrew Robertse (2010) čelí politici a politické strany obhajující mandát ve střední a východní Evropě v podstatě téměř univerzálnímu trestu a je pro ně velmi složité udržet si podporu i v následujících volbách bez ohledu na to, jak úspěšní ve svých funkcích byli. Tato zjištění, která jsou ve shodě i s našimi závěry, by si jistě zasloužila další rozpracování.

\section{Literatura a prameny ${ }^{29}$}

Abramowitz, Alan A. (1975): „Name Familiarity, Reputation, and the Incumbency Effect in a Congressional Election." The Western Political Quarterly 28(4): 668-684. DOI: $10.2307 / 447984$

Alford, John a David W. Brady (1988): Partisan and Incumbent Advantage in U.S. House Elections, 1846-1986. Houston: Center for the Study of Institution and Values.

Ansolabehere, Stephen, James Snyder a Charles Stewart (2000): „Old Voters, New Voters, and the Personal Vote: Using Redistricting to Measure the Incumbency Advantage." American Journal of Political Science 44(1): 17-34. DOI: 10.2307/2669290

Ansolabehere, Stephen a James Snyder (2004): „Using Term Limits to Estimate

Incumbency Advantages When Officeholders Retire Strategically." Legislative Studies Quarterly 29(1): 487-515. DOI: 10.3162/036298004X201276

${ }^{29}$ Dostupnost internetových zdrojů ověřena k 11. 9. 2014. 
Ashworth, Scott a Ethan B. De Mesquita (2008): „Electoral Selection, Strategic Challenger Entry, and the Incumbency Advantage." The Journal of Politics 70(4): 10061025.

Balík, Stanislav et al (2013): Vètš̌nový systém pro snèmovní volby: Ceské zkeusenosti a debaty. Brno: CDK.

Bernard, Josef (2012). „Individuální charakteristiky kandidátů ve volbách do zastupitelstev obci a jejich vliv na volební výsledky." Sociologický ćasopis 48(4): 630-640.

Brtník, Radovan a Vlastimil Havlík (2009): „Personalizace volby v kontextu konceptu voleb druhého rrádu. Případ voleb do zastupitelstva Jihomoravského kraje v roce 2008.“ Stredoevropské politické studie 11(2-3): 133-162.

Campbell, James E. (1983): „The Return of the Incumbents: The Nature of the Incumbency Advantage." The Western Political Quarterly 36(3): 434-444. DOI: $10.2307 / 448401$

Carthy, Devin a Rob Richie (2012): „Incumbency Bumps: Measuring National Partisan Swings By Evaluating the Incumbent Advantage in U.S. House Races, 1996-2012,“ online (http://www.fairvote.org/research-and-analysis/blog/incumbency-bumpsmeasuring-national-partisan-swings-by-evaluating-the-incumbent-advantage-in-u-shouse-races-1996-201/

Coop, Terri (2014): „The Advantages of Incumbency in Congressional Elections,“ online (http://www.ehow.com/info_7863060_advantages-incumbency-congressionalelections.html)

Cover, Albert D (1977): „One Good Term Deserves Another: The Advantage of Incumbency in Congressional Elections. "American Journal of Political Science 21(3): 523541. DOI: $10.2307 / 2110580$

Cox, Gary a Jonathan N. Katz (1996): „Why Did the Incumbency Advantage in U.S. House Elections Grow." American Journal of Political Science 40(2): 478-497. DOI: $10.2307 / 2111633$

Cox, Gary. W. (1997): Making Votes Count. Strategic Coordination in the World's Electoral Systems. Cambridge, New York, Melbourne: Cambridge University Press.

Cummings, Milton C. (1966): Congressmen and the electorate: elections for the U. S. House and the President, 1920-1964. New York: The Free Press.

Čaloud, Dalibor, Tomáš Foltýn a Vlastimil Havlík (2006): „Politické strany a jejich systém v období 2002-2006." In: Dalibor Čaloud et al (eds.). Volby do Poslanecké snémovny v roce 2006. Brno: CDK, 7-25.

Dvořáková, Vladimíra (2002): Spojené státy americké: společnost a politika. Praha: Libri.

Dvořáková, Vladimíra et al. (2008): Základni modely demokratických systémui. Praha: Vysoká škola ekonomická.

Erikson, Robert S. (1971): „The Advantage of Incumbency in Congressional Elections.“ Polity 3(3): 395-405. DOI: 10.2307/3234117

Erikson, Robert S. a Rocío Titiunik (2013): „Using Regression Discontinuity to Uncover the Personal Incumbency Advantage," online

(http://www.polmeth.wustl.edu/media/Paper/EriksonTitiunikpolme_1.pdf)

Farrell, David. M. (2001): Electoral Systems. A Comparative Introduction. London, New York: Palgrave Macmillan.

Filip, Jan (1997): Vybrané kapitoly ke studiu ústavního práva. Brno: Václav Klemm. 
Fowler, Anthony a Andrew B. Hall (2012): Disentangling the Personal and Partisan Incumbency Advantages: Evidence from Close Elections and Term Limits, on-line (http://papers.ssrn.com/sol3/papers.cfm?abstract_id=2120743)

Gelman, Andrew a Gary King (1990): „Estimating Incumbency Advantage without Bias.“ American Journal of Political Science 34(4): 1142-1164. DOI: 10.2307/2111475

Havlík, Vlastimil (2010): „Politické strany a jejich systém v letech 2006-2010.“ In: Stanislav Balík (ed.). Volby do Poslanecké snémovny v roce 2010. Brno: CDK, 11-38.

Holzer, Jan et al. (2009): „Jaká se produkuje politická věda? Tematická analýza publikací v českých recenzovaných politologických časopisech.“ Politologický časopis 16(2): 91-115.

Chytilek, Roman (2005a): „České senátní volby. Podněty, výsledky, alternativy." In: Břetislav Dančák, Petr Fiala a Vít Hloušek (eds.). Evropeizace: nové téma politologického výzkumu. Brno: Mezinárodní politologický ústav, 105-115.

Chytilek, Roman (2005b): „Volby 2004 a strategické účinky volebních systémů.“ Stredoevropské politické studie 6(1): 13-25.

Chytilek, Roman et al. (2009): Volebni systémy. Praha: Portál.

Jacobson, Gary C (1987): „The Marginals Never Vanished: Incumbency and Competition in Elections to the U.S. House of Representatives, 1952-82." American Journal of Political Science 31(1): 126-141. DOI: 10.2307/2111327

Katz, Jonathan a Gary King (1999): „A Statistical Model for Multiparty Electoral Data.“ American Political Science Review 93(1): 15-32. DOI: 10.2307/2585758

King, Gary a Andrew Gelman (1991). „Systemic Consequences of Incumbency Advantage in U.S. House Elections." American Journal of Political Science 35(1): 110-138. DOI: $10.2307 / 2111440$

Krehbiel, Keith a John R. Wright (1983): „The Incumbency Effect in Congressional Elections: A Test of Two Explanations.“ American Journal of Political Science 27(1): 140157. DOI: $10.2307 / 2111057$

Kreidl, Tomáš (2009): „Je chování voličů v prvním kole senátních voleb ovlivněno vlastnostmi kandidátů?" European Electoral Studies 4(2): 109-123.

Lebeda, Tomáš, Karolína Malcová a Tomáš Lacina (2009): Volby do Senátu 1996 až 2008. Praha: Sociologický ústav AV ČR.

Lebeda, Tomáš (2011): „Dopady dvoukolového většinového systému na reprezentaci stran v českém Senátu. “ Sociologický časopis 47(2): 243-271.

Lee, David S. (2001): The Electoral Advantage to Incumbency and Voters' V aluation of Politicians' Experience: A Regression Discontinuity Analysis of Elections to the $U$. S. House, on-line (https://www.princeton.edu/ davidlee/wp/w8441.pdf)

Levitt, Steven D. a Catherine D. Wolfram (1997): „Decomposing the Sources of Incumbency Advantage in U.S. House." Legislative Studies Quarterly 22(1): 45-60. DOI: $10.2307 / 440290$

Lewis-Beck, Michael a Mary Stegmaier (2000): „Economic Determinants of Electoral Outcomes." Annual Review of Political Science 3(1): 183-219. DOI: 10.1146/annurev.polisci.3.1.183

Payne, James L (1980): „The Personal Electoral Advantage of House Incumbents, 19361976.“ American Politics Research 8:(4): 465-482. DOI: 10.1177/1532673X8000800405

Praino, Rodrigo a Daniel Stockemer (2012): „Tempus Edax Rerum: Measuring the incumbency advantage in the U.S. House of Representatives." The Social Science Journal 49(3): 270-274. DOI: 10.1016/j.soscij.2012.02.002 
Raymond, Paul (1992): „The American Voter in a Nonpartisan, Urban Election.“ American Politics Quarterly 20(2): 247-260. DOI: 10.1177/1532673X9202000206

Redmond, Paul a John Regan (2013): Incumbency Advantage in Irish Elections: A Regression Discontinuity Analysis, on-line (http://economics.nuim.ie/sites/economics.nuim.ie/files/working-papers/N24113.pdf)

Roberts, Andrew (2010): The quality of democracy in Eastern Europe: public preferences and policy reforms. Cambridge: Cambridge University Press.

Ryšavý, Dan (2010): „Glossa marginalis. Nejmladší zastupitelé, co o nich víme?“ Acta Politologica 2(3): 73-85.

Sartori, Giovanni (2001): Srovnávaci ústavní inženýrství. Zkoumani struktur, podnètũ a výsledkù. Praha: Sociologické nakladatelství.

Spahn, Bradley T. (2011): Toward a Fuller Understanding of the Incumbency Advantage in State Legislative Elections: A Quasi-Experimental Approach, on-line (http://wesscholar.wesleyan.edu/cgi/viewcontent.cgi?article=1672\&context=etd_hon_ theses)

Stokes, Donald E. a Warren E. Miller (1962): „Party Government and the Saliency of Congress." Public Opinion Quarterly 26(4): 531-546.

Stone, Walter J. et al (2010): „Incumbency Reconsidered: Prospects, Strategic Retirement, and Incumbent Quality in U.S. House Elections.“ The Journal of Politics 72(1): 178-190. DOI: $10.1017 /$ S0022381609990557

Šedo, Jakub (2009): „Preferenční hlasy v komunálních volbách - zdroj obměny či stability volených reprezentantů? “ Acta Politologica 1(3): 344-365.

Trounstine, Jessica (2009): Information, Turnout, and Incumbency in Local Elections, online (https://www.princeton.edu/csdp/events/Trounstine020509/Trounstine020509.p $\mathrm{df})$

Volby.cz. 2014. On-line (http://volby.cz/)

Zákon č. 247/1995 Sb., o volbách do Parlamentu České republiky. On-line (http://www.senat.cz/senat/volby/zak247_1995.php)

\section{The Incumbency Advantage Concept In Czech Senate Elections SUMMARY}

The concept of incumbency advantage (IA) has been discussed in the literature since the 1960s. Certain authors (e. g. Stokes and Miller 1962, Cummings 1966, Erikson 1971) noticed that there is a certain advantage possessed by incumbent politicians compared to their challengers in elections to both houses of the U. S. Parliament. The most frequent explanation of IA is based on the higher quality of defenders than challengers. An incumbent candidate is perceived by voters as more competent, as he has already been elected once to the office. In addition, incumbent candidates have better access to media and broader possibilities with respect to campaign financing. Office-holders can also "scare" potential challengers (scare-off effect). Another possible explanation is that incumbent candidates use their authority for the indirect buying of votes in their district (legislative spending). Finally, voters know who the incumbent candidate in elections is and 
they can use this information as a "shortcut" that helps them in voting decision-making (Krehbiel and Wright 1983).

The main problems of empirical research on IA are the multidimensionality of the candidate's qualities such as charisma, charm and intelligence, which cannot be observed and quantified (Redmond and Regan 2013), and difficulties in distinguishing personal and partisan advantage. The two basic and most frequently used methods for dealing with these problems (Payne 1980, Gelman and King 1990) are sophomore surge (SS) and retirement slump (RS). SS can be defined as the average increase in the share of votes for a candidate who won in the previous election and contests for a mandate in the following elections. RS may be understood as the average decrease in the share of votes for a political party whose candidate won in the previous elections, but did not run in the following elections. Gelman and King (1990) show that both of these methods of calculating IA are largely inaccurate and propose their own model based on linear regression.

The aim of this work was to observe whether incumbency advantage exists in Czech Senate elections or not. At this point, however, it must be noted that the whole concept and its operationalization refer to the American political environment (the two-party system of Democrats and Republicans, the FPTP electoral system). It is therefore difficult to apply the IA concept to the Czech political system, as it is a rapidly changing multiparty system. Furthermore, the electoral system comprises two rounds. In addition, Senate elections take place in a party system that has been shaped by another type of electoral system, which means that Senate elections can be described as second-order elections (Lebeda 2011).

Our measurements focused on the first round of senate elections. We analyzed election data from all Senate elections held in the Czech Republic from 1998 to 2012. For this paper, data from the Czech Statistical Office, which publishes the results of elections on the server Volby.cz, were used. For the purposes of this work, the concepts of sophomore surge and retirement slump were also employed. Calculations were made for each party separately, distinguishing six categories (ODS, Social Democrats, Communists. KDU-CSL, Others, and Change of party affiliation). In general, these measuring instruments have a major drawback in that we cannot be sure whether they actually measure IA or not, especially in the changing multiparty system which exists in the Czech Republic. Therefore, we attempted to construct a special index which could at least partially mitigate the aforementioned difficulties. We calculated the difference between the arithmetic average of the share of votes in elections 2 and elections 1 separately for incumbents and other candidates of the same party. We calculated this index only for the most successful parties in senate elections, i. e. the ODS and CSSD.

As for the number of incumbents in elections, with the exception of 2004 there have always been between 17 and 20 incumbents running for re-election, which indicates a relatively steady state with no increasing or decreasing trend. In 2004, only 14 current senators ran, which was only half of the candidates who received a mandate in 1998. This can probably be partly explained by the success of the 4Coalition in the Senate elections in 1998, and the significant change in the party spectrum in the period from 1998 to 2004 (see Čaloud, Foltýn and Havlik 2006).

With the exception of the elections in 2000 and 2012, incumbents very often advanced to the 2 nd round. Again, we can try to explain these two cases by changes in 
the party system. Both the mentioned elections were preceded by elections (1996 and 2006) in which the two strongest parties (ODS, CSSD) more or less dominated, while the elections of 2000 and 2012 themselves were characterized by the success of the 4Coalition, respectively new parties and independent candidates (Balík et al. 2013). The number of winning incumbents was clearly highest in the 1998 elections, when 12 incumbents succeeded in the elections. In our opinion, the explanatory factor of the success may be time, as it was probably helpful to incumbents that the period between the elections was just two years compared to the usual six. Firstly, the incumbents could have been better known among voters and, secondly, smaller changes in the party system occurred in the intervening two-year period.

What, then, is the conclusion concerning incumbency advantage in Czech Republic senate elections? The total share of votes for incumbents running for re-election did not increase, implying that all counted SS values were negative. In this case, we can talk more about the disadvantage (anti-incumbency effect) of holding a mandate (see also Lebeda 2011). On average, there was a $5.52 \%$ decrease in the number of votes. Negative values also largely outweighed positive ones when calculated for each party separately. However, these data are only a partial indication of incumbency disadvantage, as, in some cases, the values are calculated on the basis of the results for one single incumbent. This fact considerably reduces the informative value of the data, though they are not completely useless.

Conversely, positive values were obtained for the average RS in all senate elections (results for parties were negative only in three cases). The average decrease in the monitored elections amounted to $6.87 \%$ of the votes. One interpretation of this is that a party actually suffers a loss if an incumbent senator withdraws from the following elections. However, in general, we cannot conclude that there is IA in Czech senate elections, since the theory assumes that the values of both SS and RS should be positive. Lastly, we calculated values of our index which compared the shares of votes of incumbents and other candidates of the CSSD and ODS. Neither of these values proved the existence of IA. The total values of the index for both parties were negative; positive values were achieved by each party only twice for particular elections.

In the literature on political systems in Central and Eastern Europe (CEE), we can find theories that explain the phenomenon that we observed; that is, the disadvantage for incumbent candidates. Andrew Roberts (2010) dealt with a phenomenon termed as electoral accountability. He examined whether there was a relationship between how successful an incumbent was in his political office and what the election results were. The conclusions of his research bring interesting data. In almost all cases, government parties reduced their share of the vote compared to the previous elections, and in many cases, the fall was very significant. Roberts therefore concluded that voters distinguish between incumbents and the opposition and punish incumbents in elections. The research showed that almost all incumbent government parties lost votes. Some lost more and some less, depending on their performance, but overall it is very difficult for incumbents in CEE to maintain electoral support, let alone improve it. Although Roberts dealt with a different electoral arena, the connection between our findings and his is quite interesting. The essence of why voters in the region so massively and universally punish incumbents is not entirely clear and is a topic that surely deserves more extensive research. 